\title{
Effects of restoration and management of Mediterranean traditional water systems on Odonata alpha diversity: a long-term monitoring survey
}

\author{
José C. Monzó ${ }^{1}$. José R. Verdú ${ }^{2}$ (D)
}

Received: 16 March 2021 / Revised: 8 November 2021 / Accepted: 9 November 2021 /

Published online: 15 November 2021

(C) The Author(s) 2021

\begin{abstract}
The progressive abandonment and disappearance of traditional water uses and management of wetlands during the twentieth century has led not only to a loss of identity, heritage, and landscape values, but also to significant declines in the diversity and abundance of many organisms. Here, we take advantage of an existing project for the restoration and management of traditional irrigation infrastructures in the wetland of El Prado (Pinoso, south-eastern Spain) to evaluate the spatio-temporal effect of this action on the alpha diversity and abundance of Odonata. The wetland was organized in different sectors according to the coverage of riparian and aquatic vegetation, width and depth of watercourses, ditches and ponds, water flow, and restoration and management. Odonates were sampled every month for ten years. We used alpha diversity to measure biodiversity using Hill's number diversity. To analyse how alpha diversity measures varied across all sectors sampled over the years, we determined diversity-time relationships. To assess the effects of the different variables on odonate biodiversity we used partial least squares regressions. Our results showed that restoration of traditional water infrastructures, encouraging the increase of aquatic vegetation cover, an adequate and regular management of riparian vegetation naturalizing the margins, as well as reducing speed of water flow have a positive effect on odonate diversity and abundance. Our study provides useful information for conservation and management of semi-arid wetlands and its associated water infrastructures by showing which actions are most successful to enhance biodiversity in one of the priority habitats for conservation in Europe.
\end{abstract}

Keywords Ecological restoration · Habitat management · Water infrastructures · Biodiversity analysis · Dragonflies · Damselflies

Communicated by Jan C. Habel.

José R. Verdú

jr.verdu@ua.es

1 Área de Medio Ambiente, Pinoso City Council, Plaza de España, 03650 Pinoso, Spain

2 Research Institute CIBIO, Universidad de Alicante, San Vicente del Raspeig, 03690 Alicante, Spain 


\section{Introduction}

The Mediterranean region has historically undergone an intense transformation in which mainly the anthropic influence on the territory has shaped a very characteristic and diverse landscape (García Antón et al. 2002). It is particularly important in the semi-arid areas of southeastern Spain, where water is the factor that has conditioned, more than in other places, the location and development of the Mediterranean populations (Silva 2012). In these areas, in past centuries, the wetlands had a high percentage of endorheic and poor drainage, but geographically they constituted the ideal space for the development of agriculture (Box 2004). Colonization and the need to cultivate vast tracts of unused land in the eighteenth and nineteenth centuries as well as illness associated with wetland fauna (Box 2004; López Pomares et al. 2014) justified the drying and transformation of the land uses of these spaces until the complete disappearance of most of them (Casado et al. 1993).

The existence of traditional water systems in inland wetlands, both for irrigation and drainage, have historically contributed to the maintenance of a unique culture and identity, but at the same time to the biodiversity of the landscape, which however has not been sufficiently studied despite its importance and its similarity to other natural river environments (López Pomares et al. 2014). Traditional irrigation systems although similar to other fluvial ecosystems, cannot be considered proper natural habitats. The landscape of inland wetlands, with their associated hydraulic infrastructures, is not understood without human intervention. The maintenance and management of these systems have focused mainly on the removal of sediment and reed (Arundo donax and Phragmites australis). It is well known that the growth and extension of reed strongly interferes with the structure and functionality of traditional water systems (water channels, ditches, rafts) (López Pomares et al. 2015). Therefore, constant maintenance and management of these spaces were necessary while human subsistence depended on them. It has been shown that reed management can strongly alter riparian habitats, producing important changes in vegetation, and consequently in fauna, for example in birdlife. These changes resulting from the type of management of the reed beds can have positive or negative effects depending on the ecological requirements of each species (Graveland 1998; Poulin and Lefebvre 2002; Poulin et al. 2002; Moreno-Mateos et al. 2009).

The effects of some management practices in wetlands on aquatic insect biodiversity are well known, as is the case with the management and cleaning of ditches. These practices could affect negatively the development of aquatic and riparian vegetation, affecting both adult and larval individuals of odonates commonly known as dragonflies and damselflies (Painter 1998). Despite this, there is still a great lack of knowledge about the impact produced by the absence of reed management (Martínez-Vilalta et al. 2002) and how the conservation and functionality of these water infrastructures contribute to the maintenance of biodiversity.

Odonates are increasingly used as bioindicators of freshwater ecosystems because of their immediate response to environmental changes (Briers and Biggs 2003; Catlin 2005). Odonates are active colonizers, appear quickly in new places, sampling methodology is simple and economically viable, mainly in the adult stage, and taxonomic characterization is up-to-date, with appropriate literature for identification, even in the field (Córdoba-Aguilar 2008; Valladares Díez et al. 2010). Due to their diversity, amphibious life history, relatively short generation time, high trophic position, and sensitivity to small-scale anthropogenic changes in the environment (Samways and Steytler 1996; Pinto et al. 2012) they have been widely used as ecological indicators of habitat quality and the integrity of freshwater 
ecosystems (Smith et al. 2007; Simaika and Samways 2011). Recent studies have valued how simple pond restoration measures increase dragonfly diversity (Janssen et al. 2018) as well as suitability of artificial water bodies according to their size and certain characteristics as habitats, for odonates (Vilenica et al. 2020). However, the ecological consequences and the loss of biodiversity of invertebrates caused by the management of traditional water systems in semi-arid Mediterranean regions have not been studied. Furthermore, there are no studies that evaluate, on a long-term basis, how recovery and restoration of these water infrastructures influence the recovery of diversity and abundance of odonates.

To know the effects of long-term management, it is necessary to undertake the functional recovery of these water infrastructures. Furthermore, the lack of knowledge of the ecological relationships that occur in these habitats can accelerate the degradation and reduction of them (López Pomares et al. 2015), causing a loss of biodiversity, mainly of those bioindicator species linked to artificial water systems, such as odonates. Therefore, the objectives of this study are (i) to analyse the diversity and abundance of odonates in a restored inland wetland and their temporal change after ten years of restoration and management; (ii) to check if the restoration actions carried out over time have favoured the diversity and abundance of odonates; (iii) and to identify which restoration actions best favour the diversity and abundance of odonates.

\section{Materials and methods}

\section{Study area and experimental design}

The study was carried out in the wetland of "El Prado" $\left(38^{\circ} 22^{\prime} 59.51^{\prime \prime} \mathrm{N} 1^{\circ} 3^{\prime 2} 26.66^{\prime \prime} \mathrm{W}\right.$, 568-555 m.a.s.1.) an area integrated into the Prado-Rodriguillo inland wetland set, in the municipality of Pinoso with an area of about 9.4 ha west of the Province of Alicante (Fig. 1). This area has a semi-arid Mediterranean climate but with some continental influence. The average annual temperature is $15.4{ }^{\circ} \mathrm{C}$ and an average rainfall of $310 \mathrm{~mm}$ (Weather Station No. 7247E Santa Catalina, Pinoso) with drought in the summer season and irregular rains in autumn. The soil of the study area contrasts clearly with the soils of the surrounding territory, basically due to the hydromorphic conditions by having the water table very close to the surface. The existence of a continuous sheet of water in the soil and subsoil, temporary or permanent waterlogging, the existence of reducing conditions and a large accumulation of organic matter are typical of these hydromorphic soils. The alternation of dry and wet periods and the presence of salts have an influence on their properties.

The El Prado wetland is part of an atomised irrigation system of traditional agricultural plots that was partially and gradually abandoned starting from the 1970s. This system is made up of a network of more than $1 \mathrm{~km}$ of irrigation ditches and watercourses, as well as various ponds, which to date have been little studied in terms of heritage (Garrigós 2016). These ditches, some of which may date from the nineteenth century or even older, in the absence of studies dating their age, were used to irrigate the crops that were once grown in the area. But as agriculture is currently in decline, there is a change of use of the land towards low-density residential urban development or the simple abandonment of these plots of land. The abandonment of agriculture and the change in land uses has led to the deterioration and loss of ditches, waterways, and rafts both physically and functionally, causing flooding problems. 


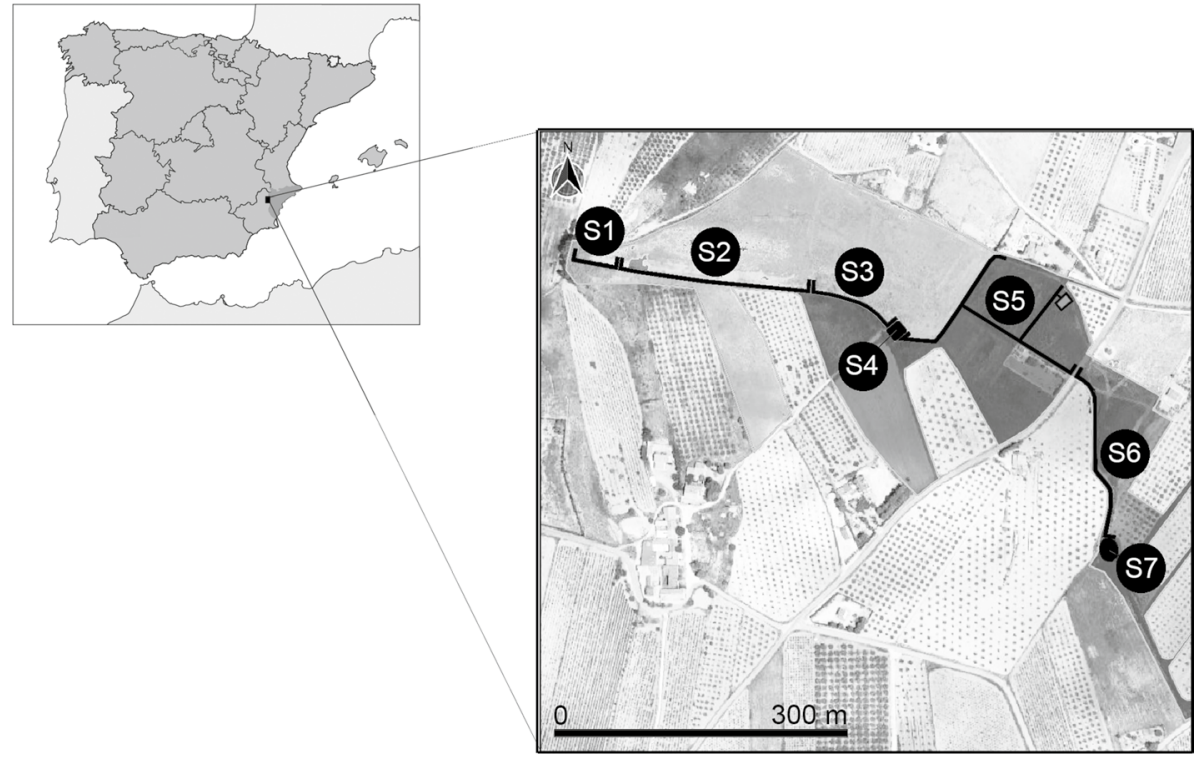

Fig. 1 Map of the study area showing the location of the studied sectors in the "El Prado-Rodriguillo" wetland (SE Spain)

The first actions of landscape and functional recovery of the water infrastructures present in the wetland of El Prado began in 2003. The Environment Office (Área de Medioambiente) of the City of Pinoso in collaboration with other institutions and environmental volunteers, decided to act on the problems of flooding in crop fields due to the destruction of the old drainage network of the agrarian system. These measures were initially aimed at resolving a conflict through the rehabilitation of the old irrigation and drainage network to prevent flooding of land and crops. As of 2008, it is considered that the restoration work of ditches, channels and ponds has restored water functionality in most of the study area. It is at that moment when the work of restoration and management of vegetation, sediments, planting, improvement or adaptation of the water infrastructures themselves for the benefit of biodiversity begins. Therefore, before 2008 , the system did not meet the best conditions for the odonates, because the work required certain sectors of the system to be kept without water from time to time. In addition, in certain areas there was neither riparian nor aquatic vegetation due to the restoration work itself or the opposite could take place with an excess of vegetation as in the case of collapsed areas of reed bed.

The measured environmental parameters of the water that flow and run through the restored ditches, channels and rafts give a range of average temperature values of $16-18^{\circ} \mathrm{C} \pm 0.5, \mathrm{pH}: 7.0-8.4 \pm 0.1$, conductivity: $3800-4200 \pm 2 \% \mu \mathrm{S}$, and dissolved oxygen concentration: $5.38 \pm 0.80 \mathrm{mg} / \mathrm{l}-77.6 \% \pm 9.2 \%$. Measurements were taken every month (12 measurements per year for each parameter) using the HANNA HI991301 and HANNA HI981983 pH/EC/TDS portable meters.

Prior to the beginning of the ecological restoration project, the irrigation water system was classified in sectors, based on the environmental and hydromorphological heterogeneity, storage and drainage of the El Prado wetland, to evaluate the effects of the restoration and management of this wetland on the diversity of the Odonata (Fig. 1 and Table 1). The criteria used to characterise each sector were: 


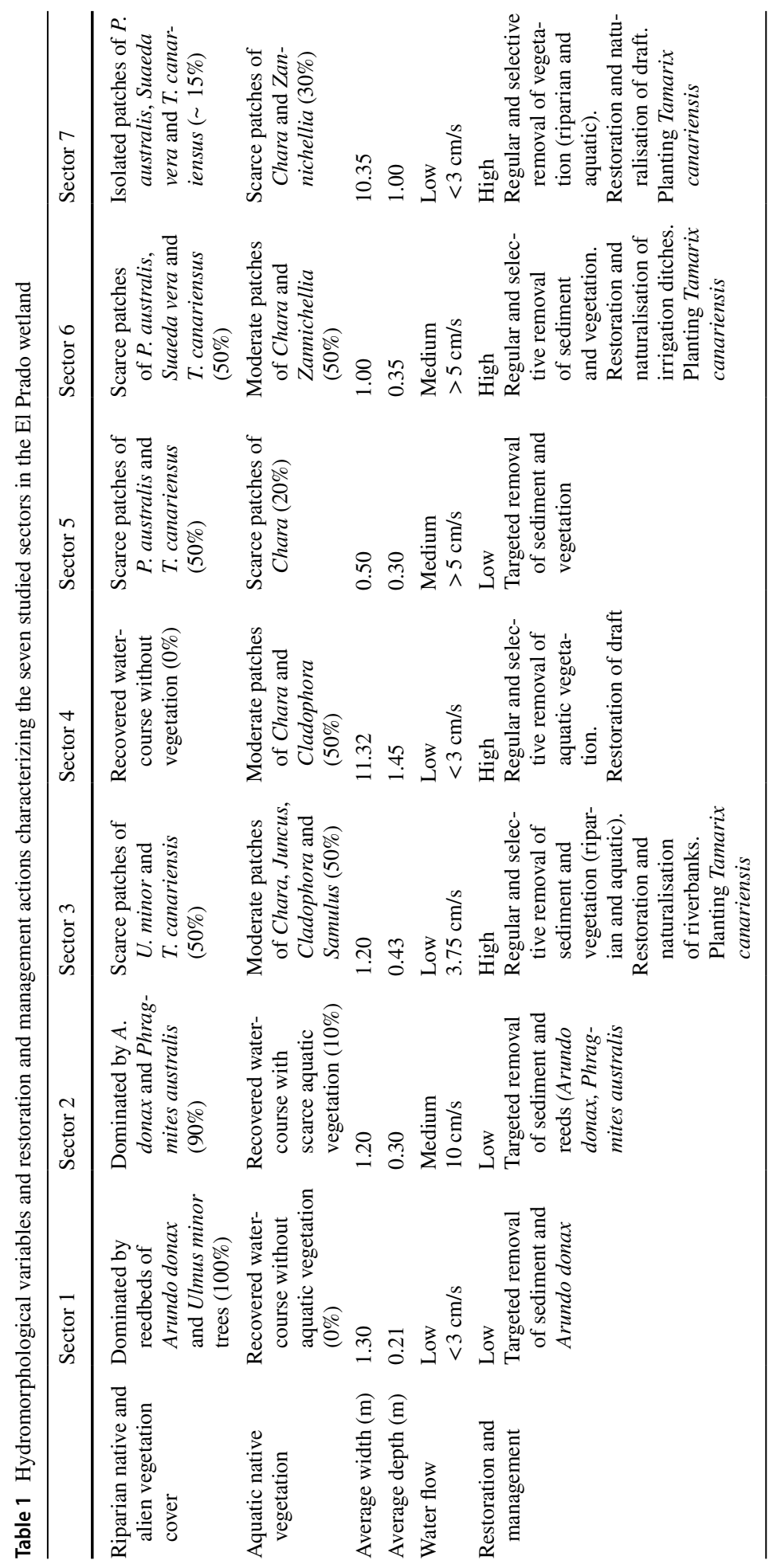


(1) Riparian vegetation coverage: The riparian vegetation cover changed in each of the different sectors, in both species composition and density. The species and their density are conditioned by their management, the presence of reed (Phragmites australis and the exotic Arundo donax) and wood species such as elms (Ulmus minor) and tarais (Tamarix canariensis). Vegetation cover classes were measured using the Braun-Blanquet visual assessment technique (Poore 1955; Westhoff and Van Der Maarel 1978). This method is very quick, requiring only a few minutes at each sampling site; however, it is robust and highly repeatable, minimising differences between observers. Riparian vegetation inventories were carried out annually in August (summer) and November (autumn).

(2) Aquatic vegetation: The most common submerged and floating macrophytes belong to the Chara, Samolus, Zannichellia and Cladophora genera. Some species of these genera are frequently used by odonates for roosting, oviposition and for the development and shelter of immature stages (Amstrong 1978; Fincke 1982; Hunger 1998). Density classes were also measured using the Braun-Blanquet visual assessment technique. Taxonomic identification was made according to Cirujano-Bracamonte (2014). Aquatic vegetation inventories were carried out annually in August (summer) and November (autumn).

(3) Width and depth: The width and depth of rafts, riverbeds and ditches differ throughout the study area. The average width range is $0.50-10.35 \mathrm{~m}$ and the average depth range is $0.21-1.45 \mathrm{~m}$. Width and depth were measured with a graduate, flexible metal tape measure. Measurements were carried out annually in August (summer) and November (autumn).

(4) Water flow: The height gradient of the study area and the different slopes of the riverbeds and ditches in each of the sectors condition the speed of the flow and therefore the adaptation of each species to these conditions. Surface water flow was measured by the simple method of calculating the time in seconds that it takes for a piece of wood to travel the distance between two distant points. Measurements were carried out annually in August (summer) and November (autumn).

(5) Restoration and management. The restoration measures, management and maintenance in space and time have been different in each sector. Restoration recovers the functionality of the system as well as the presence and flow of water in rafts and ditches. Maintenance is mainly focused on the selective management of the vegetation. The main restoration and management actions that were carried out regularly and constantly focused on: (i) exhaustive removal of Arundo donax, control of the density of Phragmites australis, (ii) selective removal of aquatic vegetation, (iii) removal of sediment and organic matter and (iv) enlargement of width and depth of watercourses and ditches. The specific and lower intensity measures only focused on the removal of organic matter (mainly dry vegetation remains), and the selective removal of vegetation at points of flow obstruction. Given the complexity of establishing a quantitative variable from these actions based on the work already carried out in a restoration project by the Pinoso Town Council, it was decided to treat this variable as categorical with three levels (high, medium and low), as it appears in Table 1. 


\section{Odonata sampling}

For this study, we have sampled the Odonate assemblage of the wetland annually since 2009 to 2018. In each sector, within a year, sampling was conducted three times each month, beginning in January and ending in December. During each sampling event in each sector, three three-hour transects were conducted. Adult specimens were sampled by visual identification using Ricoh-Pentax Papilio II $8.5 \times 21$ binoculars and dual cameras Sanyo VPC-HD2 and Sanyo VPC-HD2000. Although sampling of exuviae is used in studies to evaluate odonates (Heidemann and Seidenbusch 2002; Raebel et al. 2010) as evidence for the local presence of a species (Janssen et al. 2018), in this work only adult specimens of Anisoptera and Zygoptera have been sampled. As the work was longterm (ten years), there was no assurance of continuity in sampling, so methods tended to be simplified and standardised. As a consequence, the study of larvae and exuviae, much more complex from the point of view of sampling and taxonomic identification (Oertli 2008) and that may underestimate the richness and abundance of species (Bried et al. 2012) had to be discarded. Thus, adult odonates were considered good indicators of freshwater wetland conditions and spatial heterogeneity of the different biotopes (Steytler and Samways 1995; Kutcher and Bried 2014). Most specimens were identified visually without having to be captured. In the few cases where capture was necessary for identification, the specimen was immediately released after a few minutes.

\section{Sampling completeness}

To know the completeness of the sampling in all sectors, a sample coverage analysis was performed (Chao and Jost 2012). This is a measure of sample completeness, and reveals the proportion of the total number of individuals in a community which belongs to the species represented in the sample. Measurements were taken using iNEXT (Chao et al. 2016).

\section{Alpha diversity measurement}

We have used the alpha diversity component to measure biodiversity. Alpha diversity was calculated using Hill's numbers family diversity (McArthur 1965; Hill 1973; Jost $2006,2007)$. These diversity measures are parameterized by the order $q$. The $q$ parameter determines the sensitivity of the index in relation to rare or abundant species. For example, the diversity of $q=0$ is completely insensitive to species abundance and so corresponds to species richness; for $q=1$, species are weighted proportionally to their relative abundance and corresponds to the Shannon entropy exponential; for $q=2$ the index is disproportionately sensitive to common species and corresponds to the reciprocal of the Simpson index (Jost 2006, 2007). The results of these indices are expressed in terms of the "effective number of species", i.e., the number of equally abundant species needed to produce the same value of the diversity measure (Jost 2006, 2007). These measures conform to the replication principle introduced by Hill (1973). The diversity profile at different $q$ levels were performed using the values for $q=0, q=1$ and $q=2$ per year and sector. These were obtained with the Past v4.03 software (Hammer 2001). 


\section{Temporal variation of alpha diversity and abundance}

To analyse how alpha diversity measures varied across all sampled sectors along the years, we determined the diversity-time relationships (DTR) calculating the slopes using both linear and semi-logarithmic functions and least-squares regressions to determine linear relationships. This procedure was also carried out to determine the average DTR throughout the wetland. All data were analysed using the software Prism v8.4.0 for Macintosh, GraphPad Software, San Diego California, USA.

\section{Effects of restoration management and hydromorphology on alpha diversity and abundance}

To evaluate the effects of the different variables (restoration measures, riparian vegetation cover, aquatic vegetation, depth, width, and flow of watercourses) on biodiversity of odonates in the wetland studied, we used Partial Least Squares Regressions (PLSR). PLSR finds latent components that are linear combinations of many multicollinearity predictors and can maximize the explained variance, identifying the most relevant parameters that are capable of explaining the effect on biodiversity measures. Data were analysed using StatSoft's Statistica 12 (StatSoft Inc., Tulsa, Oklahoma, USA).

\section{Results}

A total of 4253 adult specimens of Odonata belonging to 29 species, 15 genera and five families were recorded, of which 18 species correspond to the suborder Anisoptera (dragonflies) and 11 species to the suborder Zygoptera (damselflies) (Table 2). The sample coverage estimator revealed that our inventories were $99 \%$ complete in six of the seven sectors sampled and 93\% complete in the remaining sector. Thus, we considered our samples to be complete, and we can apply empirical data for the diversity analysis.

\section{Alpha diversity and abundance over time}

After ten years of recovery of the wetland, the DTRs obtained showed a general increase in Odonata diversity and abundance (see Table 3). Linear regressions were fitted with a greater goodness of fit $\left(R^{2}\right)$ than the semi-logarithmic regressions, so the calculations were performed with linear functions without logarithmic transformations (Fig. 2). All sectors showed positive diversity-time relationships (DTR), ranged from 0.27 to 1.59 species year $^{-1}, 0.14-1.03$ species year ${ }^{-1}$, and $0.12-0.82$ species year ${ }^{-1}$, for ${ }^{0} D,{ }^{1} D$, and ${ }^{2} D$, respectively. The abundancetime relationship (NTR) showed positive slopes between 2.13 and 46.90 individuals year $^{-1}$ (Table 3). Average values of DTR in the wetland were $0.91,0.50$ and 0.36 species year $^{-1}$ for ${ }^{0} D,{ }^{1} D$, and ${ }^{2} D$, respectively. For abundance data, average NTR was 13.90 individuals year ${ }^{-1}$ (Table 3). 
Table 2 Odonate species and individuals recorded at El Prado wetland during 2009-2018

\begin{tabular}{|c|c|c|c|c|c|c|c|c|c|c|}
\hline Species & 2009 & 2010 & 2011 & 2012 & 2013 & 2014 & 2015 & 2016 & 2017 & 2018 \\
\hline Aeshna cyanea & 0 & 0 & 0 & 0 & 0 & 22 & 1 & 1 & 1 & 0 \\
\hline Aeshna mixta & 0 & 0 & 0 & 0 & 0 & 4 & 0 & 0 & 6 & 2 \\
\hline Anax ephippiger & 0 & 0 & 0 & 0 & 0 & 0 & 0 & 0 & 3 & 0 \\
\hline Anax imperator & 1 & 3 & 9 & 3 & 12 & 16 & 21 & 21 & 33 & 17 \\
\hline Anax parthenope & 0 & 0 & 1 & 2 & 0 & 16 & 3 & 0 & 5 & 0 \\
\hline Calopteryx haemorrhoidalis & 0 & 1 & 1 & 1 & 0 & 3 & 24 & 105 & 51 & 29 \\
\hline Ceriagrion tenellum & 1 & 0 & 2 & 11 & 23 & 301 & 234 & 304 & 86 & 136 \\
\hline Coenagrion caerulescens & 0 & 2 & 14 & 1 & 12 & 0 & 22 & 9 & 1 & 13 \\
\hline Coenagrion mercuriale & 0 & 0 & 1 & 0 & 0 & 0 & 30 & 53 & 59 & 55 \\
\hline Crocothemis erythraea & 1 & 3 & 8 & 16 & 13 & 33 & 26 & 23 & 53 & 19 \\
\hline Enallagma cyathigerum & 0 & 0 & 0 & 0 & 0 & 2 & 1 & 0 & 0 & 0 \\
\hline Erythromma lindenii & 0 & 0 & 0 & 0 & 0 & 1 & 12 & 12 & 109 & 72 \\
\hline Ischnura graellsii & 1 & 42 & 128 & 6 & 84 & 86 & 49 & 45 & 92 & 103 \\
\hline Ischnura pumilio & 2 & 0 & 1 & 0 & 7 & 2 & 2 & 0 & 1 & 1 \\
\hline Lestes barbarus & 0 & 0 & 0 & 0 & 0 & 0 & 0 & 0 & 1 & 0 \\
\hline Chalcolestes viridis & 0 & 0 & 0 & 0 & 0 & 0 & 0 & 0 & 8 & 2 \\
\hline Orthetrum brunneum & 0 & 4 & 4 & 2 & 24 & 11 & 21 & 35 & 27 & 21 \\
\hline Orthetrum cancellatum & 1 & 2 & 0 & 0 & 4 & 9 & 11 & 10 & 30 & 17 \\
\hline Orthetrum chrysostigma & 0 & 0 & 2 & 0 & 2 & 28 & 3 & 23 & 19 & 9 \\
\hline Orthetrum coerulescens & 0 & 15 & 8 & 42 & 16 & 54 & 162 & 116 & 117 & 64 \\
\hline Orthetrum nitidinerve & 0 & 0 & 0 & 0 & 0 & 0 & 0 & 0 & 0 & 1 \\
\hline Orthetrum trinacria & 0 & 1 & 0 & 1 & 0 & 0 & 0 & 0 & 0 & 0 \\
\hline Selysiothemis nigra & 0 & 0 & 0 & 0 & 0 & 0 & 0 & 0 & 0 & 1 \\
\hline Sympecma fusca & 0 & 0 & 0 & 0 & 0 & 1 & 0 & 0 & 0 & 0 \\
\hline Sympetrum fonscolombii & 0 & 5 & 4 & 8 & 9 & 53 & 13 & 8 & 56 & 7 \\
\hline Sympetrum sinaiticum & 0 & 5 & 2 & 7 & 13 & 22 & 0 & 10 & 23 & 21 \\
\hline Sympetrum striolatum & 0 & 3 & 0 & 6 & 9 & 21 & 2 & 8 & 12 & 4 \\
\hline Trithemis annulata & 0 & 0 & 0 & 0 & 0 & 0 & 3 & 0 & 0 & 0 \\
\hline Trithemis kirbyi & 0 & 0 & 0 & 0 & 0 & 31 & 13 & 25 & 57 & 20 \\
\hline Total & 7 & 86 & 185 & 106 & 228 & 716 & 653 & 808 & 850 & 614 \\
\hline
\end{tabular}

Table 3 Diversity-time relationships (DTR) of Odonata using different Hill numbers $(q=0,1$ and 2$)$ and Abundancetime relationships (NTR) during 2009-2018 in different hydromorphological sectors in the El Prado wetland

\begin{tabular}{lrrrrrrrr}
\hline & S1 & S2 & \multicolumn{1}{l}{ S3 } & S4 & S5 & S6 & S7 & Mean \\
\hline${ }^{0} \mathrm{DTR}$ & 0.42 & 0.27 & 1.14 & 0.72 & 0.85 & 1.59 & 1.35 & 0.91 \\
$R^{2}(\%)$ & 53.63 & 47.57 & 68.83 & 75.42 & 40.24 & 75.37 & 74.52 & 27.32 \\
${ }^{1} \mathrm{DTR}$ & 0.25 & 0.14 & 0.29 & 0.47 & 0.43 & 0.88 & 1.03 & 0.50 \\
$R^{2}(\%)$ & 59.94 & 33.37 & 26.49 & 54.90 & 44.15 & 54.59 & 70.35 & 23.13 \\
${ }^{2} \mathrm{DTR}$ & 0.20 & 0.12 & 0.14 & 0.34 & 0.27 & 0.60 & 0.82 & 0.36 \\
$R^{2}(\%)$ & 59.40 & 30.19 & 8.72 & 40.78 & 30.33 & 37.95 & 64.90 & 18.17 \\
$\mathrm{NTR}$ & 2.13 & 7.98 & 46.90 & 5.24 & 6.55 & 22.90 & 5.61 & 13.90 \\
$R^{2}(\%)$ & 57.43 & 49.62 & 64.79 & 51.96 & 13.10 & 58.92 & 28.86 & 15.82 \\
\hline
\end{tabular}

The sectors are coded by S1-S7 

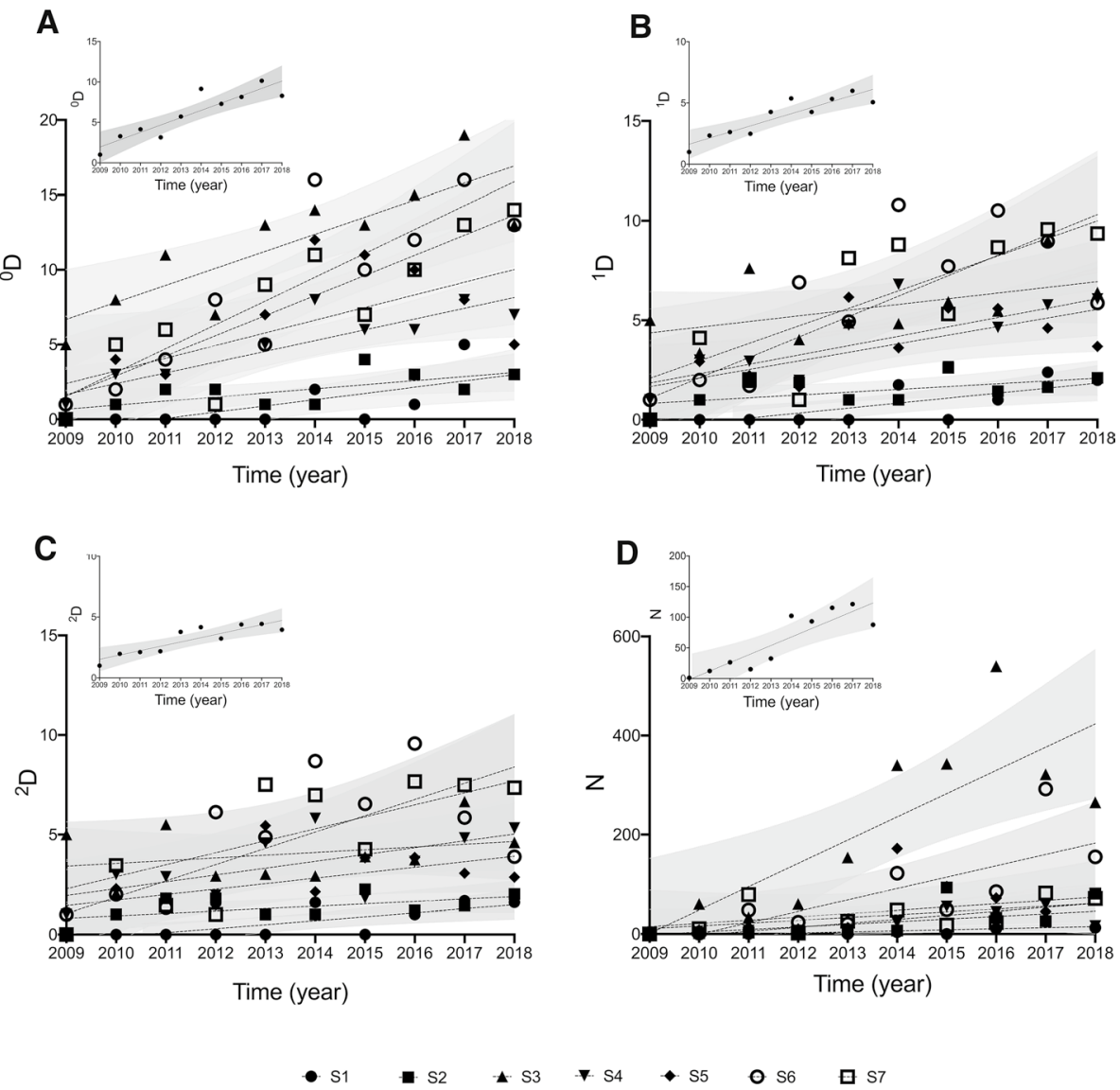

Fig. 2 Diversity-time (DTR) and abundance-time (NTR) relationships of Odonata in the seven sectors at the El Prado wetland from 2009 to 2018 . A DTR at $q=0$; B DTR at $q=1$; DTR at $q=2$; and C NTR. Small graphs in each case correspond to average values

\section{Effects of restoration management and hydromorphology on alpha diversity and abundance}

A single significant PLSR component was obtained, which relates to response to restoration and management, border vegetation cover, aquatic vegetation, width, depth and flow of water bodies. Results showed that the highest DTRs at all $q$ levels analysed were associated, in order of relevance, with the highest levels of restoration management, lowest levels of riparian vegetation cover, highest levels of aquatic vegetation, and with the deepest and widest watercourses (Fig. 3; Table 4). In other words, the restoration measures carried out in the wetland and the maintenance of the aquatic vegetation were determinants to explain the increase of Odonata biodiversity. On the contrary, the least recovered sectors and with the highest density of riparian vegetation were those with the least diversity of odonates observed. 


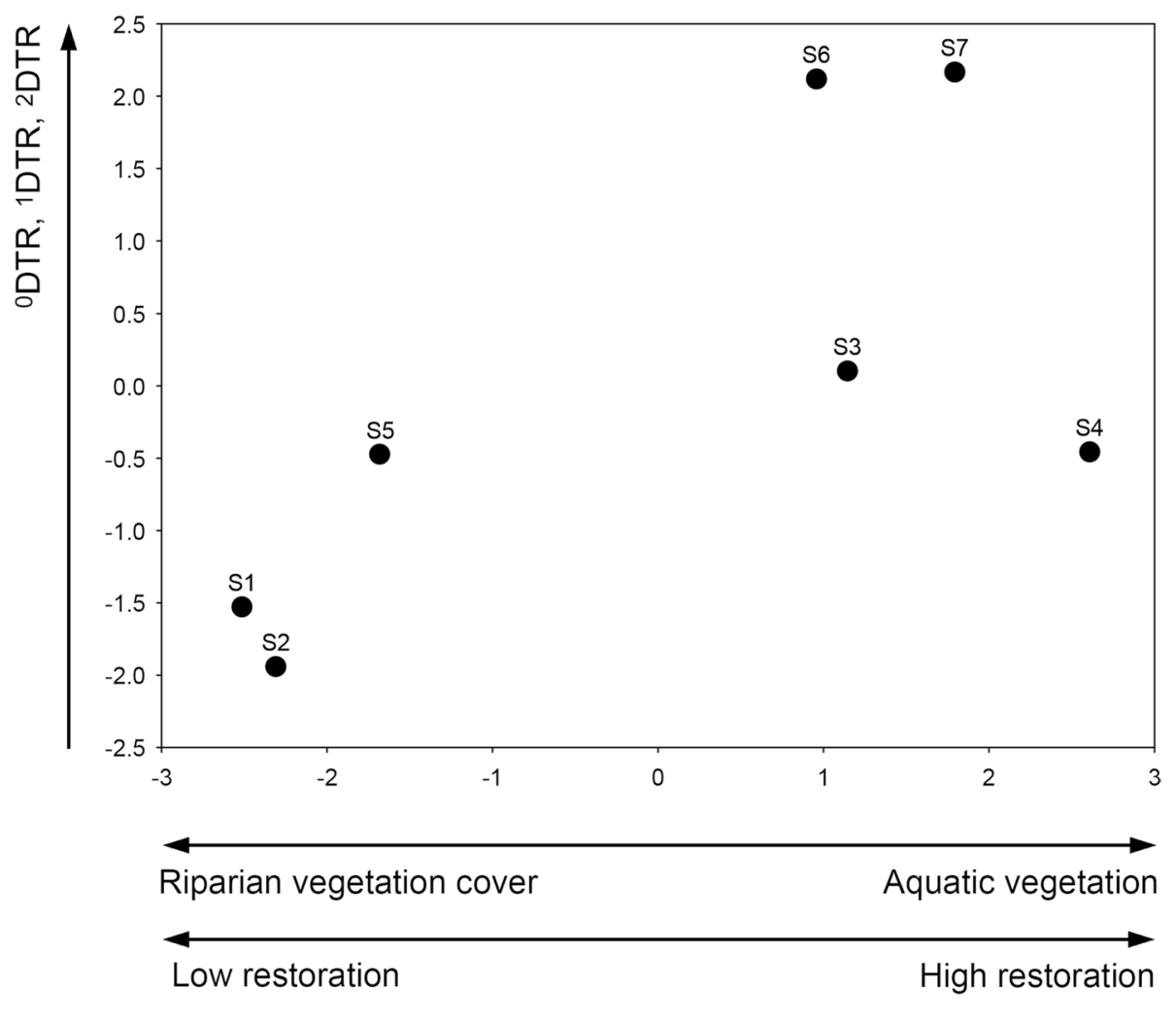

Depth riverbed, width riverbed

Fig. 3 Relationships between the PLSR component for the response variables and predictors obtained. Results showed that the highest DTRs at all $q$ values analysed were positively associated, in order of relevance, with the highest levels of restoration management, lowest levels of riparian vegetation cover, highest levels of aquatic vegetation, and with the deepest and widest watercourses

\section{Discussion}

Our results supported the hypothesis that restoration of traditional water infrastructures, encouraging the increase of aquatic vegetation cover, an adequate and regular management of riparian vegetation naturalizing the margins, as well as reducing speed of water flow have a positive effect on odonate diversity and abundance. In this work, 'true diversity' measures were used $\left({ }^{q} D\right)$, so it has been found that the increase in biodiversity has not only occurred in terms of species richness $\left({ }^{0} D\right)$. The increase of ${ }^{1} D$ reinforced the idea that the populations of the odonates have been successfully established from 2009 , increasing the effective number of species and therefore, being an indicator of the establishment and stability of the different ecological niches they require. In addition, the increase in ${ }^{2} D$ gives even more evidence since it indicates that over time there were no events that strongly benefited one species over another in a dominant way showing a trend towards equitativity between populations of the different species. 
Table 4 Results of the Partial Least Squares Regression (PLSR) analysis summarizing the effects of restoration management and hydromorphology on alpha diversity and abundance of odonates in the El Prado wetland (SE Spain)

\begin{tabular}{lrr}
\hline & PLSR component & $R^{2}(\%)$ \\
\hline $\begin{array}{l}\text { Response variables } \\
{ }^{0} \text { DTR }\end{array}$ & $\mathbf{0 . 6 0}$ & 35.48 \\
${ }^{1}$ DTR & $\mathbf{0 . 5 5}$ & 30.32 \\
${ }^{2}$ DTR & $\mathbf{0 . 5 1}$ & 25.89 \\
NTR & 0.29 & 8.31 \\
R $^{2}$ \%) & 62.24 & \\
Predictors & & \\
Restoration & $\mathbf{0 . 4 6}$ & \\
Riparian vegetation & $\mathbf{- 0 . 4 3}$ & \\
Aquatic vegetation & $\mathbf{0 . 4 2}$ & \\
Depth (mean) & $\mathbf{0 . 3 8}$ & \\
Width (mean) & $\mathbf{0 . 3 4}$ & \\
Water flow & 0.21 & \\
Eigenvalues & 4.45 & \\
\hline
\end{tabular}

The variables whose square weights are larger than $1 /$ number of variables (four response and six predictor variables; i.e., magnitude effect larger than that expected by chance) are indicated in bold type font

Stable systems, with low flow and well-oxygenated waters and a heterogeneous aquatic and riparian vegetation structure that acts as a refuge and innkeeper, allowed a rapid increase of the biodiversity of the odonates. From 2009 onwards, the restoration and management of the different hydromorphological sectors increased the heterogeneity of niches and suitable microhabitats for larvae and adults of odonates. For example, the larvae of Odonata use stalks from sedges to emerge from the water and molt (Osborn and Samways 1996). In addition, a well-developed pond shore with natural tall reeds or other structurally similar riparian vegetation serve for stalking their prey and as a refuge from predators, and in the case of adults for innkeepers (Corbet and Brooks 2008), thermoregulation (Pezalla 1979), and as an indicator of suitable aquatic conditions for larval development (Buchwald 1992; Osborne and Samways 1996). On the contrary, the homogeneity of riparian vegetation by domination of the invasive great reed (Arundo donax) that formed dense stands along several sectors within the El Prado wetland influenced negatively on odonate diversity and abundance. Several Odonata species have been reported to be particularly threatened by invasive plant species along watercourses (Samways and Taylor 2004). In the case of A. donax, several spatio-temporal studies observed a decline in the populations of odonates that coincided with extensive growth of this reed (Moore 1991; Balzan 2012). From an ecosystemic point of view, the high density of $A$. donax impoverishes the riparian native flora and subsequently the arthropod fauna, thus changing the riparian food webs (Maceda-Veiga et al. 2016). Here, management actions focused on A. donax removal were carried out regularly to promote the restoration of natural riparian vegetation increasing habitat heterogeneity and so the biodiversity of odonates.

For larvae, submerged aquatic vegetation, the vegetation type more significantly related to odonate diversity in El Prado wetland, promotes diversity at the sector scale by increasing habitat complexity (Kadoya et al. 2004), providing foraging habitat for the larvae (Sagrario et al. 2009) and cover from natural enemies (Corbet 1999). On the contrary, large coverages of aquatic macrophytes (e.g., Cladophora prolifera and 
Zannichellia peltata) favour the absence of dissolved oxygen in water (Vilenica et al. 2020; Rose and Crumpton 1996), which requires maintenance in the El Prado wetland to prevent the traditional water system from collapsing, seeking a balance between slow currents and density of submerged vegetation. Our results clearly showed that these management actions along a time scale favoured at least the proliferation of diverse aquatic vegetation and the maintenance of low water flows that allow the correct oxygenation of the water, as well as the laying of eggs and larval development of both Anisoptera and Zygoptera species.

Thus, traditional irrigation systems are not self-sustaining because of their anthropogenic character. Their maintenance and functionality have been conditioned to constant management, mainly by controlling invasive riparian vegetation (e.g., A. donax) and preventing the proliferation of massive aquatic vegetation (e.g., C. prolifera), as we have already seen. Several studies showed that the construction of artificial water bodies can provide suitable habitats for odonates (Vilenica et al. 2020; Renner et al. 2016) and that they colonize them quickly (Askew 2004) but can also constitute traps (Harabiš and Dolný 2012), hence the need for appropriate management of these infrastructures. Our results are in line with those obtained by Schindler et al. (2003); Rouquette and Thompson (2005), Vilenica et al. (2020) where it was also observed that the strong increase in odonate biodiversity we found after restoration confirms the sensitive response that odonates have whenever the structure and integrity of macrophyte vegetation are modified or altered.

Another aspect that influences the richness of odonate species is the recovery of the diversity of the wetland habitats that surround the network of channels, ditches, and ponds. The abandonment of agriculture in the El Prado wetland and the timely application of protection regulations have enabled the recovery of some of the vegetation and fauna associated with these described habitats, favouring the flooding of land typical of a wetland area. Hydraulic infrastructures, unable to fulfil their main functions, which are irrigation and drainage, raise water tables and flood the land, which favours the recovery of their natural habitats. For Odonata, these fragile systems constitute a large part of their foraging areas and help to protect the watercourses in which they are born, live and feed. For this reason, the protection of the vegetation around watercourses is one of the basic protection measures proposed by specialists for the conservation of Odonata and especially in the Mediterranean area (San Miguel 2009).

Although the role of odonates as environmental indicators must continue to be studied, mainly their sensitivity to pollution, they can be a useful tool for identifying and evaluating local diversity hotspots and monitoring biodiversity changes in time. They show the potential of these fragile systems for recovery of ecosystem services if appropriate environmental recovery projects are undertaken. In our study, odonates act as indicators of success in restoring and managing traditional water systems, however, the recovery of this wetland has favoured other taxonomic groups that have synergistically given greater conservation value to the wetland. An example is the reintroduction of the Endangered Spanish killifish Apricaphanius iberus, which has increased its population exponentially since 2004 (unpublished data). Another example is the pond turtle Mauremys leprosa a Vulnerable species en Europe, which in 2010 was identified in two specimens and nowadays, the number of individuals exceeds 30 (unpublished data).

Finally, based on our results, a list of conservation actions can be recommended that must necessarily be accompanied by measures to regulate access and activities in restored areas as well as to designate restricted biodiversity conservation areas to reduce anthropogenic pressure (Table 5). 


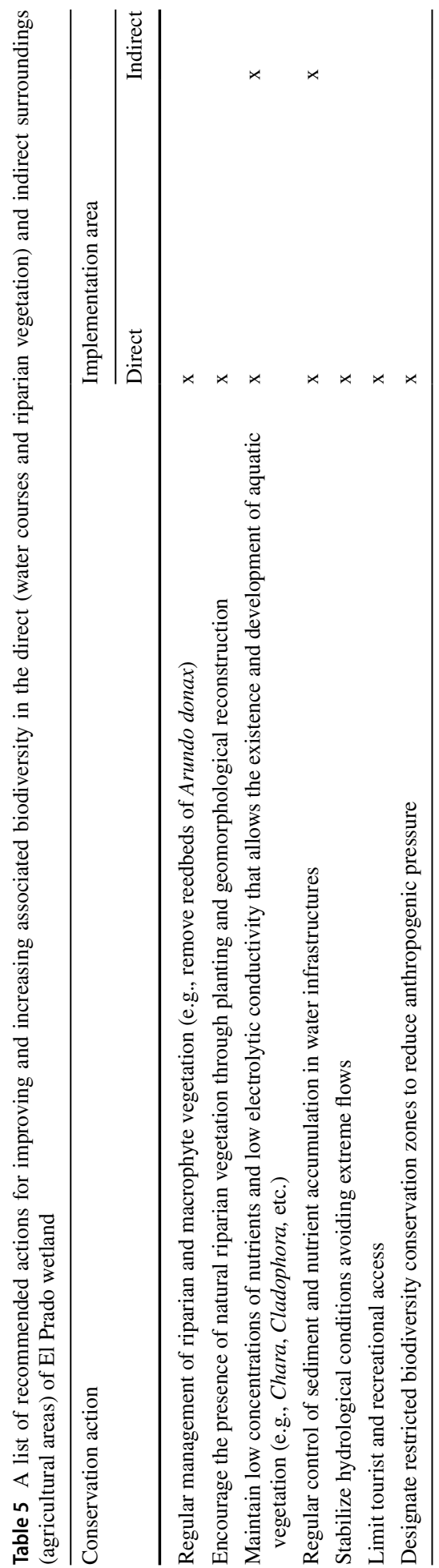


Acknowledgements We sincerely appreciate the contribution of environmental volunteers from Pinoso and especially Jacobo Ramos for his tireless work in collecting data over the years, which has made this study possible. Their altruistic work contributes greatly to the inventories of species and the knowledge of their distribution.

Funding Open Access funding provided thanks to the CRUE-CSIC agreement with Springer Nature.

Data availability The datasets generated during the current study are available from the corresponding author on reasonable request.

\section{Declarations}

Conflicts of interest The authors declare that they have no conflict of interest.

Open Access This article is licensed under a Creative Commons Attribution 4.0 International License, which permits use, sharing, adaptation, distribution and reproduction in any medium or format, as long as you give appropriate credit to the original author(s) and the source, provide a link to the Creative Commons licence, and indicate if changes were made. The images or other third party material in this article are included in the article's Creative Commons licence, unless indicated otherwise in a credit line to the material. If material is not included in the article's Creative Commons licence and your intended use is not permitted by statutory regulation or exceeds the permitted use, you will need to obtain permission directly from the copyright holder. To view a copy of this licence, visit http://creativecommons.org/licenses/by/4.0/.

\section{References}

Amstrong JS (1978) Colonization of New Zealand by Hemicordulia australiae, with notes on its displacement of the indigenous Procordulia grayi (Odonata: Corduliidae). New Zeal Entomol 6(4):381-384. https://doi.org/10.1080/00779962.1978.9722297

Askew RR (2004) The dragonflies of Europe, 2nd edn. Harley Books, Colchester, p 308. https://doi.org/10. 1111/j.1096-3642.2006.00265.x

Balzan MV (2012) Associations of dragonflies (Odonata) to habitat variables within the Maltese Islands: a spatio-temporal approach. J Insect Sci. https://doi.org/10.1673/031.012.8701

Box Amorós M (2004) Humedales y áreas lacustres de la provincia de Alicante. Monografías. Publicaciones de la Universidad de Alicante 456

Bried JT, Hager BJ, Hunt PD, Fox JN, Jensen HJ, Vowels KM (2012) Bias of reduced-effort community surveys for adult Odonata of lentic waters. Insect Conserv Divers 5:213-222. https://doi.org/10.1111/j. 1752-4598.2011.00156.x

Briers RA, Biggs J (2003) Indicator taxa for the conservation of pond invertebrate diversity. Aquat Conserv 13(4):323-330. https://doi.org/10.1002/aqc.576

Buchwald R (1992) Vegetation and dragonfly fauna: characteristics and examples of biocenological field studies. Plant Ecol 101(2):99-107. https://doi.org/10.1007/BF00033195

Casado S, Florín Beltrán M, Montes C (1993) La desecación del paisaje. Evaluación de la pérdida de superficie de humedales en la España peninsular. In: Martín JF, Sánchez FL, Tardío T (eds) Agua y Paisaje. Asociación para el Estudio del Paisaje, Segovia (Spain), pp 77-89. https://doi.org/10.13140/2.1.3462. 3360

Catlin PA (2005) A potential for the use of dragonfly (Odonata) diversity as a bioindicator of the efficiency of sewage lagoons. Can Field Nat 119(2):233-236. https://doi.org/10.22621/cfn.v119i2.111

Chao A, Jost L (2012) Coverage-based rarefaction and extrapolation: standardizing samples by completeness rather than size. Ecology 93(12):2533-2547. https://doi.org/10.2307/41739612

Chao A, Ma KH, Hsieh TC (2016) User's for INEXT online: software for interpolation and extrapolation of species diversity. Institute of Statistics, National Tsing Hua University. https://doi.org/10.13140/RG.2. 2.25777.79200

Cirujano Bracamonte S, Meco Molina A, García Murillo PM, Chirino Argenta M (2014) Flora acuática española. Hidrófitos vasculares. Real Jardín Botánico, CSIC, Madrid 320

Corbet PS (1999) Dragonflies. Behaviour and ecology of Odonata. Harley Books, Colchester, p 829

Corbet PS, Brooks S (2008) Dragonflies. Collins New Naturalist Library No. 106. HarperCollins 480 
Córdoba-Aguilar A (ed) (2008) Dragonflies and damselflies. Model organisms for ecological and evolutionary research. Oxford University Press, Oxford, p 288. https://doi.org/10.1007/s10841-009-9217-2

Fincke OM (1982) Lifetime mating success in a natural population of the damselfly, Enallagma hageni (Walsh) (Odonata: Coenagrionidae). Behav Ecol Sociobiol 10(4):293-302. https://doi.org/10.1007/ BF00302820

García-Antón M, Maldonado Ruiz J, Morla Juaristi C, Sainz-Ollero H (2002) Fitogeografía histórica de la Península Ibérica. In: F.D. Pineda, J.M. de Miguel, M.A. Casado, J. Montalvo (Eds), La diversidad biológica de España, Pearson Educación, S.A. Prentice Hall, pp. 45-64.

Garrigós i Albert I (2016) El patrimoni etnoarqueològic a la zona humida del Prado (El Pinós, Alacant): una valoració per al seu estudi i difusió. In Memoria Viva. Publicació del projecte Patrimoni del Programa d'Extensió Universitària. Universitat Jaume I de Castelló, 93-98.

González Sagrario MA, Balseiro E, Ituarte R, Spivak E (2009) Macrophytes as refuge or risky area for zooplankton: a balance set by littoral predacious macroinvertebrates. Freshwater Biol 54(5):1042-1053. https://doi.org/10.1111/j.1365-2427.2008.02152.x

Graveland J (1998) Reed die-back, water level management and the decline of the great reed warbler Acrocephalus arundinaceus in The Netherlands. Ardea 86(2):187-201

Hammer $\varnothing$, Harper DAT, Ryan PD (2001) PAST: paleontological statistics software package for education and data analysis. Paleontol Electron 4(1):9

Harabiš F, Dolný A (2012) Human altered ecosystems: suitable habitats as well as ecological traps for dragonflies (Odonata): the matter of scale. J Insect Conserv 16(1):121-130. https://doi.org/10. 1007/s10841-011-9400-0

Heidemann H, Seidenbusch R (2002) Die Libellenlarven Deutschlands: Handbuch für Exuviensammler. Die Tierwelt Deutschlands und der angrenzenden Meeresteile, Goecke and Evers, Keltern, Germany, 328

Hill MO (1973) Diversity and evenness: a unifying notation and its consequences. Ecology 54(2):427432. https://doi.org/10.2307/1934352

Hunger H (1998) Biozönologische untersuchungen zum habitatschema der Pokal-Azurjungfer (Cercion lindenii SÉLYS 1840) in der südlichen Oberrheinebene, Naturschutz südl. Oberrhein 2:159-166

Janssen A, Hunger H, Konold W, Pufal G, Staab M (2018) Simple pond restoration measures increase dragonfly (Insecta: Odonata) diversity. Biodivers Conserv 27(9):2311-2328. https://doi.org/10. 1007/s10531-018-1539-5

Jost L (2006) Entropy and diversity. Oikos 113(2):363-375. https://doi.org/10.1111/j.2006.0030-1299. 14714.x

Jost L (2007) Partitioning diversity into independent alpha and beta components. Ecology 88(10):24272439. https://doi.org/10.1890/06-1736.1

Kadoya T, Suda S-I, Washitani I (2004) Dragon y species richness on man-made ponds: effects of pond size and pond age on newly established assemblages. Ecol Res 19(5):461-467. https://doi.org/10. 1111/j.1440-1703.2004.00659.x

Kutcher TE, Bried JT (2014) Adult Odonata conservatism as an indicator of freshwater wetland condition. Ecol Indic 38:31-39. https://doi.org/10.1016/j.ecolind.2013.10.028

López Pomares A, López-Iborra GM, Martín Cantarino C (2014) Importancia de las infraestructuras de riego tradicionales en la conservación de la avifauna en el entorno de humedales protegidos: el caso de Carrizales de Elche. Irrigation, Society, Landscape. Tribute to Thomas F. Glick, Editorial, Universitat Politècnica de València, 751-762. https://doi.org/10.4995/ISL2014.2014.189

López Pomares A, López-Iborra GM, Martín Cantarino C (2015) Irrigation canals in a semi-arid agricultural landscape surrounded by wetlands: their role as a habitat for birds during the breeding season. J Arid Environ 118:28-36. https://doi.org/10.1016/j.jaridenv.2015.02.021

Maceda-Veiga A, Basas H, Lanzaco G, Sala M, De Sostoa A, Serra A (2016) Impacts of the invader giant reed (Arundo donax) on riparian habitats and ground arthropod communities. Biol Invasions 18(3):731-749. https://doi.org/10.1007/s10530-015-1044-7

Martínez-Vilalta J, Bertolero A, Bigas D, Paquet J-Y, Martínez-Vilalta A (2002) Habitat selection of passerine birds nesting in the Ebro delta reedbeds (NE Spain): management implications. Wetlands 22(2):318-325. https://doi.org/10.1672/0277-5212(2002)022[0318:HSOPBN]2.0.CO;2

McArthur R (1965) Patterns of species diversity. Biol Rev 40(4):510-533

Moore NW (1991) The development of dragonfly communities and the consequences of territorial behaviour: a 27 year study on small ponds at Woodwalton Fen, Cambridgeshire, United Kingdom. Odonatologica 20(2):203-231

Moreno-Mateos D, Pedrocchi C, Comín FA (2009) Avian communities' preferences in recently created agricultural wetlands in irrigated landscapes of semiarid areas. Biodivers Conserv 18(4):811-828. https://doi.org/10.1007/s10531-008-9472-7 
Oertli B (2008) The use of dragonflies in the assessment and monitoring of aquatic habitats. In: Dragonflies and Damselflies. Model organisms for ecological and evolutionary research. Oxford University Press. Chapter 7: 79-95. https://doi.org/10.1093/acprof:oso/9780199230693.003.0007

Osborn R, Samways MJ (1996) Determinants of adult dragonfly assemblage patterns at new ponds in South Africa. Odonatologica 25(1):49-58

Painter D (1998) Effects of ditch management patterns on Odonata at Wicken Fen, Cambridgeshire, UK. Biol Conserv 84(2):189-195. https://doi.org/10.1016/S0006-3207(97)00095-5

Pezalla VAM (1979) Behavioral ecology of the dragonfly Libellula pulchella Drury (Odonata: Anisoptera). Am Midl Naturalist 102(1):1-22. https://doi.org/10.2307/2425062

Pinto NS, Juen L, Cabette HSR, De Marco P (2012) Fluctuating asymmetry and wing size of Argia tinctipennis selys (Zygoptera: Coenagrionidae) in relation to riparian forest preservation status. Neotrop Entomol 41(3):178-185. https://doi.org/10.1007/s13744-012-0029-9

Poore M (1955) The use of phytosociological methods in ecological investigations: II. Practical issues involved in an attempt to apply the braun-blanquet system. J Ecol. https://doi.org/10.2307/2257133

Poulin B, Lefebvre G (2002) Effect of winter cutting on the passerine breeding assemblage in French Mediterranean reedbeds. Biodiver Conserv 11(9):1567-1581. https://doi.org/10.1023/A:1016866116220

Poulin B, Lefebvre G, Mauchamp A (2002) Habitat requirements of passerines and reedbed management in southern France. Biol Conserv 107:315-325. https://doi.org/10.1016/S0006-3207(02)00070-8

Raebel EM, Merckx T, Riordan P, Macdonald DW, Thompson DJ (2010) The dragonfly delusion: why it is essential to sample exuviae to avoid biased surveys. J Insect Conserv 14(5):523-533. https://doi.org/ 10.1007/s10841-010-9281-7

Renner S, Périco E, Sahlén G (2016) Man-made lakes form species-rich dragonfly communities in the Brazilian Atlantic Forest (Odonata). Odonatologica 45(3):135-154. https://doi.org/10.5281/zenodo. 163441

Rose C, Crumpton WG (1996) Effects of emergent macrophytes on dissolved oxygen dynamics in a prairie pothole wetland. Wetlands 16(4):495-502. https://doi.org/10.1007/BF03161339

Rouquette J, Thompson DJ (2005) Habitat associations of the endangered damselfly, Coenagrion mercuriale, in a water meadow ditch system in southern England. Biol Conserv 123(2):225-235. https://doi. org/10.1007/s10841-006-9030-0

Samways MJ, Steytler NS (1996) Dragonfly (Odonata) distribution patterns in urban and forest landscapes, and recommendations for riparian management. Biol Conser 78(3):279-288. https://doi.org/10.1016/ S0006-3207(96)00032-8

Samways MJ, Taylor S (2004) Impacts of invasive alien plants on Red-Listed South African dragonflies (Odonata). S Afr J Sci 100(1-2):78-80. http://hdl.handle.net/10019.1/9687. Accessed 13 Jan 2021

San Miguel A (2009) 6420 Comunidades herbáceas higrófilas mediterráneas. En: VV.AA., Bases ecológicas preliminares para la conservación de los tipos de hábitat de interés comunitario en España. Madrid: Ministerio de Medio Ambiente, y Medio Rural y Marino. Madrid. 54

Schindler M, Fesl C, Chovanec A (2003) Dragonfly associations (Insecta: Odonata) in relation to habitat variables: a multivariate approach. Hydrobiologia 497(1):169-180. https://doi.org/10.1023/A:10254 76220081

Silva Pérez R (2012) Claves para la recuperación de los regadíos tradicionales. Nuevos contextos y funciones territoriales para viejas agriculturas. Scripta Nova. Vol. XVI (412).

Simaika JP, Samways MJ (2011) Comparative assessment of indices of freshwater habitat conditions using different invertebrate taxon sets. Ecol Indic 11(2):370-378. https://doi.org/10.1016/j.ecolind.2010.06. 005

Smith J, Samways MJ, Taylor S (2007) Assessing riparian quality using two complementary sets of bioindicators. Biodivers Conserv 16(9):2695-2713. https://doi.org/10.1007/s10531-006-9081-2

Steytler NS, Samways M (1995) Biotope selection by adult male dragonflies (Odonata) at an artificial lake created for insect conservation in South Africa. Biol Conserv 72(3):381-386. https://doi.org/10.1016/ 0006-3207(94)00052-R

Valladares Díez LF, García Criado F, Mazé González RA, Miguélez Carbajo M, Vega Moreno FJ (2010) Estudio de la comunidad de Odonatos de los parques del Anillo Verde de Vitoria-Gasteiz. Instituto de Medio Ambiente, Recursos Naturales y Biodiversidad. Universidad de León. 127

Vilenica M, Pozojević I, Vučković N, Mihaljević Z (2020) How suitable are man-made water bodies as habitats for Odonata? Knowl Manage Aquat Ecosyst 421(421):13. https://doi.org/10.1051/kmae/2020008

Westhoff V, Van der Maarel E (1978) The Braun Blanquet approach. In: Classification of Plan Communities. Springer Netherlands 287-399. https://doi.org/10.1007/978-94-010-2701-4_20

Publisher's Note Springer Nature remains neutral with regard to jurisdictional claims in published maps and institutional affiliations. 